\title{
Verification of Safety of Containers for Spent Nuclear Fuel by Thermal and Pressure Tests
}

\author{
František Trebuňa *, František Šimčák, Jozef Bocko, Miroslav Pástor, Peter Frankovský and \\ Patrik Šarga
}

'Technical University of Košice, Faculty of Mechanical Engineering, Department of Applied Mechanics and Mechatronics, Letná 9, 04200 Košice

\begin{abstract}
František Trebuňa, Dr.h.c. mult. prof. Ing. CSc. (1947) is a professor of applied mechanics, Dean of the Faculty of Mechanical Engineering of Technical University of Košice. He is author of 12 monographs, 13 university textbook, special book publications, 12 university notebooks and more than 350 publications in journals and conference proceedings in Slovakia and abroad. He is also author of important projects and engineering works. His professional and scientific orientation is oriented to experimental and numerical methods of mechanics, prediction lifetime of structure, stress and strain analysis, photoelasticimetry, redistribution of stresses, modal analysis. He received several prizes at home and abroad. He received three honorary Doctor Honoris Causa (Dr.h.c.) including two from foreign universities for the development of applied mechanics and mechatronics and last year he received Honorary Doctorate of Letters (For the extraordinary contribution in the area of creation, development and publication activity in the scientific branches of applied mechanics and mechatronics), IBC Cambridge, England. At the beginning of 2014 he received State prize he got "Honour of Ludovit Štúr of the 2nd order". Prof. Trebuña is a member of several Scientific councils on technical universities in Slovakia and abroad and member of editorial boards of journals.
\end{abstract}

František Šimčák, prof. Ing. CSc. (1947) is a professor of applied mechanics, Head of the Department of Applied Mechanics and Mechatronics. He is author of 8 monographs, 11 university textbook, 6 university notebooks and more than 250 publications in journals and conference proceedings in Slovakia and abroad. He is co-author of important projects and engineering works. He received several prizes due to his scientific results. His professional and scientific orientation is oriented to strength and stiffness analysis of thin-walled elements and structures, computational and experimental stress analysis of structural elements made of classical and composite materials, plastic properties of steel sheets and lifetime of structures. He is a member of Scientific council of the Faculty of Mechanical Engineering, Technical University of Košice.

Jozef Bocko, prof. Ing., CSc. (1959) is a professor of applied mechanics. He is author of 2 monographs, 9 university textbook and more than 200 publications in journals and conference proceedings in Slovakia and abroad. He is author and co-author of important projects and engineering works. His professional and scientific interests are oriented to the finite element method, nonlinear mechanics, shell theory, application of Lie groups in mechanics. He is a member of Scientific council of the Faculty of Mechanical Engineering, Technical University of Košice and member of council of Slovak Association of Mechanics by Slovak Academy of Sciences.

Miroslav Pástor, doc. Ing., PhD. (1975) is a associated professor of applied mechanics on the Department of Applied Mechanics and Mechatronics. In 2008 he received PhD. in the field of applied mechanics. In 2013 he habilitated in the area of applied mechanics. He is author of 2 monographs, 3 university textbook and more than 60 publications in journals and conference proceedings at Slovakia and abroad. He is co-author of important projects and engineering works. He made remarkable work on the building of laboratories and on publication of monographs and university textbook at the department. His professional and scientific orientation is oriented to experimental 
mechanics, prediction lifetime of structure, stress and strain analysis, photoelasticimetry. He is a member of Slovak Association of Mechanics by Slovak Academy of Sciences.

Peter Frankovský, doc. Ing., PhD. (1982) is a associated professor of applied mechanics on the Department of Applied Mechanics and Mechatronics. In 2010 he received PhD. in the field of applied mechanics. In 2014 he habilitated in the area of applied mechanics. He is author of 2 monographs, 3 university textbook and more than 90 publications in journals and conference proceedings at Slovakia and abroad. He is co-author of important projects and engineering works. He made remarkable work on the building of laboratories and on publication of monographs and university textbook at the department. His professional and scientific interests are oriented to numerical and experimental methods of mechanics, stress and strain analysis and Photostress. He is a member of Slovak Association of Mechanics by Slovak Academy of Sciences and member of the Scientific and Organizing Committee of the International Conference: Modelling of mechanical and mechatronics systems MMaMS.

Patrik Šarga, Ing. PhD. (1979). He graduated in „Automation and Control in Mechanical Engineering" at Technical University of Košice in 2002. He was an internal PhD. student at the Department of Applied Mechanics and Mechatronics and in 2005 he defended his dissertation thesis in field of Mechatronics. Nowadays he works as an assistant on the Department of Applied Mechanics and Mechatronics at the Faculty of Mechanical Engineering at Technical University of Košice. He is co-author of three books of lecture notes and more than 70 publications in journals and conference proceedings in Slovakia and abroad, e.g. Engineering Failure Analysis, Metalurgija. He has worked on several grant projects, research tasks and many projects solved for industry realized on the department.

Abstract: During safety verification of containers for transport spent nuclear fuel is useful to use a combination of experimental and numerical methods of mechanics. According to present regulations, they have to comply with prescribed tests realized on real containers or their models that have the same basic properties as evaluated object. In the paper are given experimental as well as numerical treatments for safety verification of containers under thermal and pressure loading together with presentation of reached results.

Keywords: Safe operation, container for transport of nuclear fuel, experimental and numerical methods of mechanics.

\section{Introduction}

For the approval process of packages (containers, casks) that are determined for transport of radioactive materials is necessary to realize analyses affirming that transport package fulfill demands of regulation UJD SR No.57/2006 Z.z. [1]. For the safety assessment is possible to use analytical and numerical computations as well as experimental treatments that manifest fulfillment of demands for packages in accordance to Addendum No. 4 of above-mentioned regulation.

On the workplace of authors was recently realized verification of particular types of packages in accordance with regulation $[2,3,4,5]$. During the verification process were employed procedures of analytical and numerical modeling in accordance with international standards [6, 7]. Object of investigation by numerical and experimental analysis was container for transportation of spent radioactive fuel (Fig. 1a) with basic dimensions according to Fig. 1b.

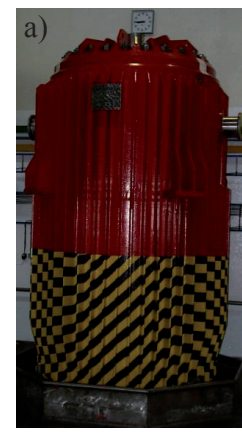

b)

Fig. 1: (a) Container for transportation of spent radioactive fuel. (b) Basic dimensions of container.

For realization part of tests was manufactured model in scale 1:8 according to Fig. 2 .
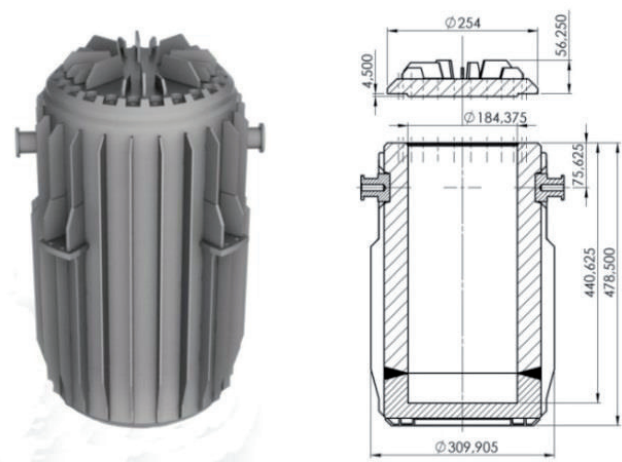

Fig. 2: Model of container for realization several tests. 
The model was produced with preserving rules of geometrical and physical similarity. In the paper is given procedure for safety verification of container under thermal loading (on real container) as well as external pressure (on container model) by using experimental and numerical methods of mechanics $[8,9,10]$.

\section{Thermal Test of Container}

The aim of thermal analysis of transport container is to approve that after its filling by nuclear fuel rods, the generated heat energy can be dragged away under prescribed transport and test conditions and that allowed limit temperatures and stresses are not crossed [1].

According to Regulation No. 57/2006 Z.z. Part VIII, outer temperature for container in operation can lie in the range $-40^{\circ} \mathrm{C}$ to $+38^{\circ} \mathrm{C}$. According to Subsection 14 Part VIII, temperature on any easy accessible part of container surface cannot exceed $85^{\circ} \mathrm{C}$. It is the reason why it is necessary to determine safety parameters and these confirm by experimental and numerical methods. The authors have chosen, after agreement with operator, the test based on heating of working media in the container. The test is based on installation of heating coils in hinged bin.

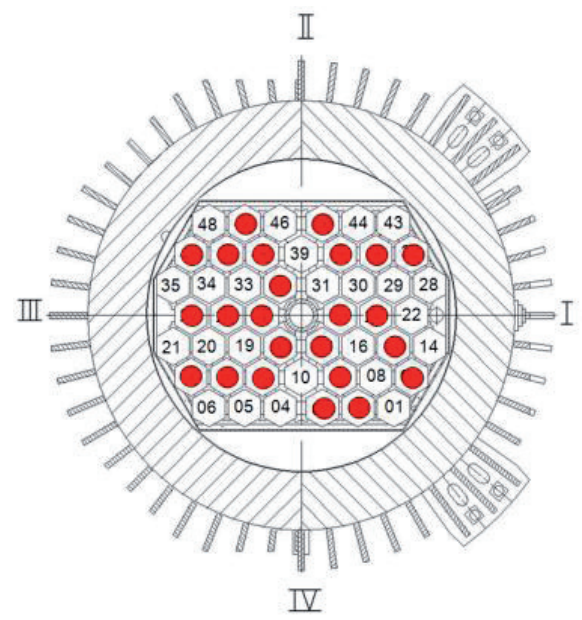

Fig. 3: Distribution of heating coils in cassette boxes of container.
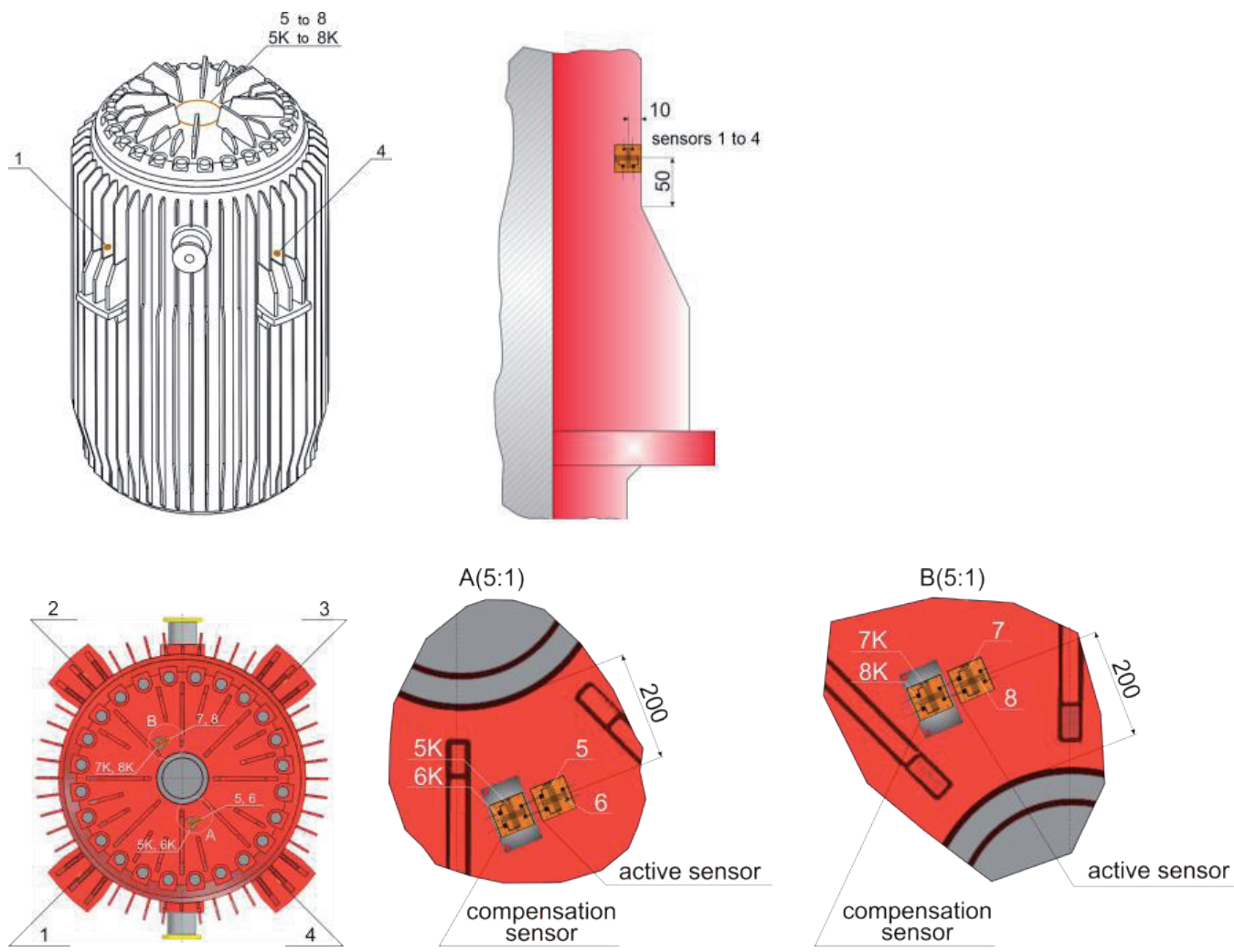

Fig. 4: Localization of strain gages on the body of container. 
Electrical heating of container space filled by water has simulated residual heat released by spent nuclear fuel. The regulation system of container heating ensured continuous regulation of heating input to maximum value of $28,8 \mathrm{~kW}$. At the same time, it allowed measurement of real heating input. 24 heating coils of power $1.2 \mathrm{~kW}$ accomplished heating and regulation was based on thyristor control units. Before measurement, installation of heating coils, sealing and filling of container by nitrogen to pressure $0.2 \mathrm{MPa}$ had been accomplished. In Fig. 3 is shown distribution of heating coils in container cassettes bins.

It is obvious form Fig. 3 that the distribution of coils is not symmetric and it can result to slight irregularity in temperature distribution. In order to identify loading due to heating, on the container body were applied 8 strain gages, while 4 measurement locations were on cooling ribs over fixation flanges and 4 (in pairs, because of plane stress state) were applied on the lid of container. Location of strain gages on the container body is given in Fig. 4.

In order to ensure thermal compensation, in the locations of plane stress state, there were applied compensative strain gages $5 \mathrm{~K}$ to $8 \mathrm{~K}$ on unloaded steel sheets near to active strain gages [11]. Numbers 5 to 8 mark the active strain gages.

The strain gage measurements were accomplished during three days in four positions on fixation flanges and four sensors on two locations on a lid, Fig. 4.

At that time worked heating coils and there was measured temperature of water in the container cassette as well as temperatures of surface and environment. A thermal imaging camera also registered the temperatures of container surface. The charts of measured temperatures in individual time instants are given in Fig. 5. Deliberate switching off air-conditioning in a room where the container was situated caused the change of environment temperature before end of measurement. In the location of sensor was reached maximum approximately $65^{\circ} \mathrm{C}$, while the temperature of water was tightly under $80^{\circ} \mathrm{C}$.

An example of measured values of strains due to heating is shown in Fig. 6. The graphs represent time-dependent charts of strains during time periods when without switching off heating was measured continuously increment of strains. Splitting

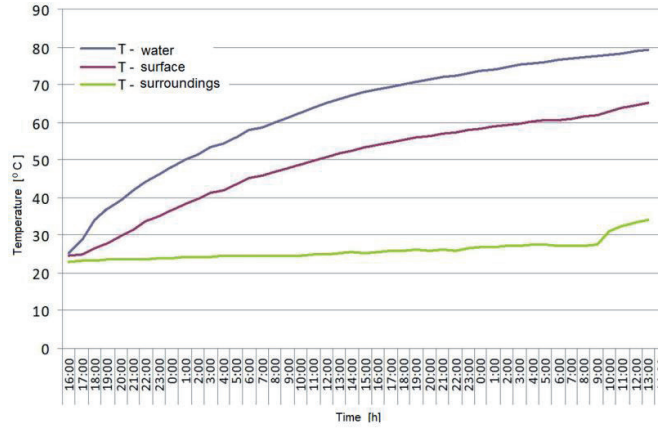

Fig. 5: Time-dependent charts of temperatures (water, surface, surroundings).

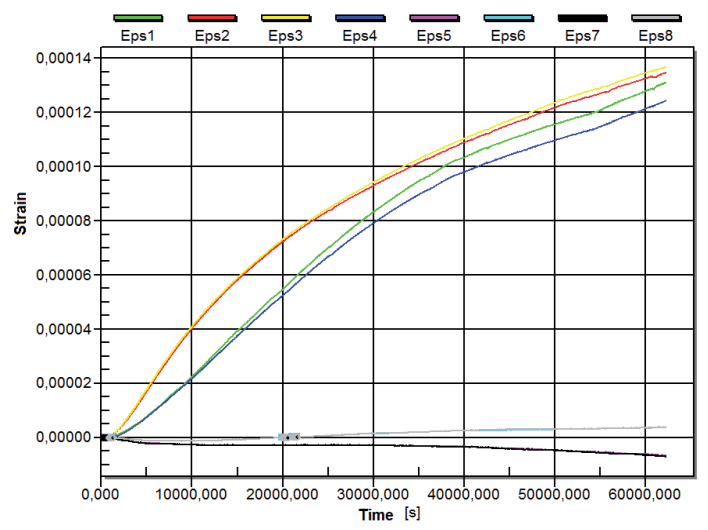

Fig. 6: Time-dependent charts of strains during thermal test No.1.

of whole measurement into shorter time periods was caused by effort to keep data of measurement even in case of apparatus or storage media failure.

In graph in Fig. 7 are given time-dependent charts of stresses during whole measurement.

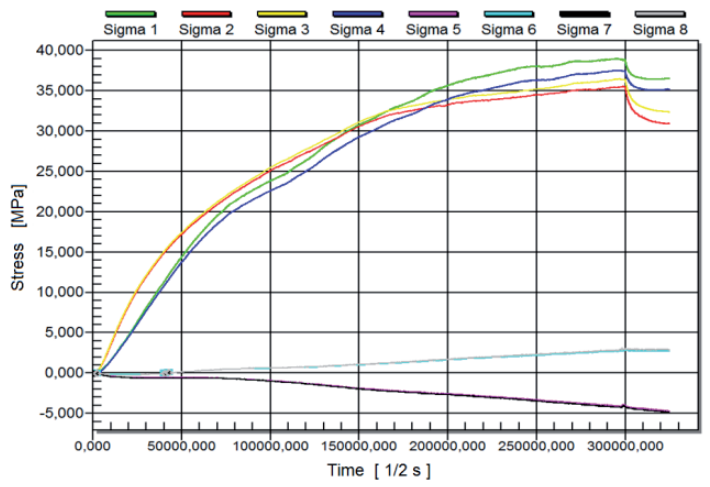

Fig. 7: Time-dependent charts of stresses during the whole thermal test. 
Broken curves in time-dependent charts of stresses (time approximately $150000 \mathrm{~s}$ ) were caused by switching off air-conditioning in the room, where the container was placed. At the time, when the air conditioner was turned off, the temperature of environment increased, while the increment of water temperature was constant (Fig. 5) and surface temperature increased. This results to decreasing of stresses in ribs (locations 1 to 4 in Fig.7).

The temperature of container surface was scanned by thermal imaging camera TiR1 during the whole thermal test. In Fig. 8a is an example of photograph of container in the area of temperature measurement and in Fig. 8b is given corresponding detail of container surface scanned by thermal imaging camera.

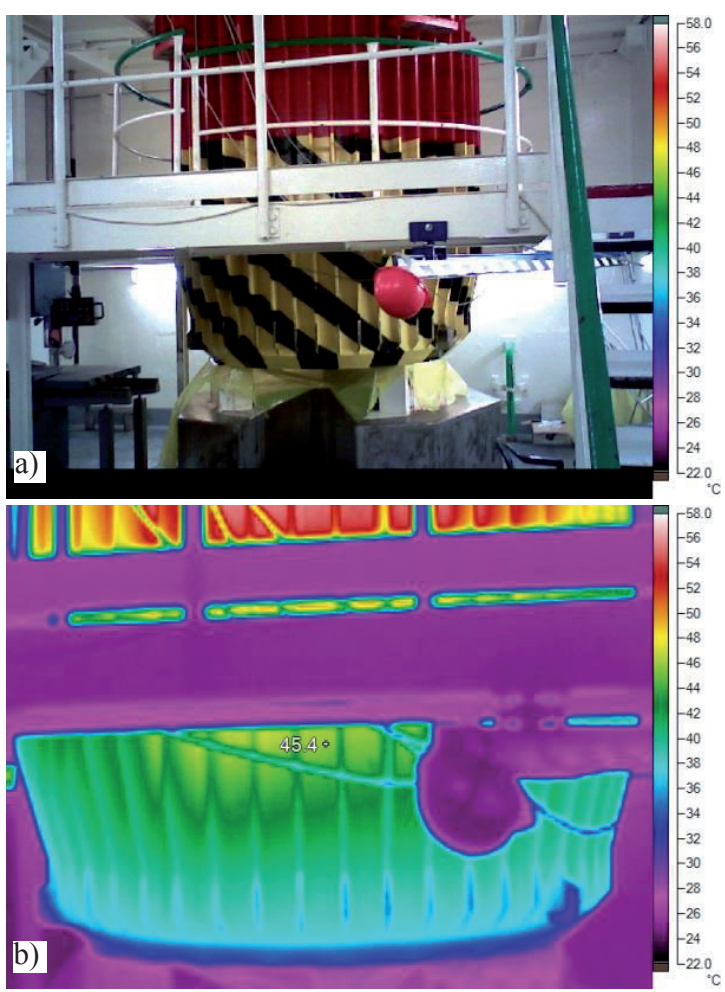

Fig. 8: Measurement on the outer surface of container. (a) View to bottom part of container. (b) Detail of thermal field on the container surface taken by thermal imaging camera.

Simulation of thermal states was realized in the frame of computational verification of container. Here are given only short results in order to simplify verification by experiment and with thermal fields gained by thermal imaging camera.

Simulations of thermal states of container were accomplished by the finite element method (FEM). Computational model consists of threedimensional finite elements. The container model is shown in Fig. 9a, individual parts of model (container body, lid of container, bolts, fuel cassettes, water, nitrogen) are shown in Fig. 9b.

a)
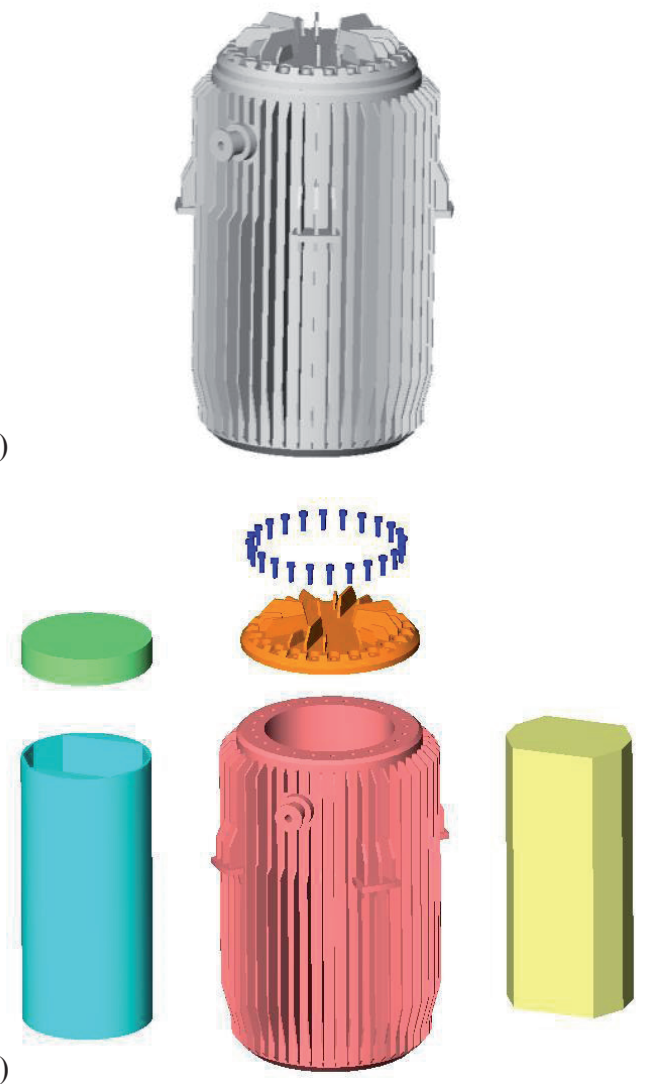

b)

Fig. 9: (a) Assembly of computational model. (b) Parts of computational model.

As an example of comparison of numerical simulation and experiment we present here numerical simulation where the container is given into environment with temperature $38^{\circ} \mathrm{C}$ and outer surface temperature of container is approximately $80^{\circ} \mathrm{C}$.

In Fig. 10 is given temperature distribution on the surface of container with limiting maximum temperature $85^{\circ} \mathrm{C}$ assigned to red color.

The fields of equivalent stresses according to von Mises theory for above given thermal fields are shown in Fig. 11.

During the experimental determination of stresses in locations 1 and 4 on cooling ribs and in loca- 

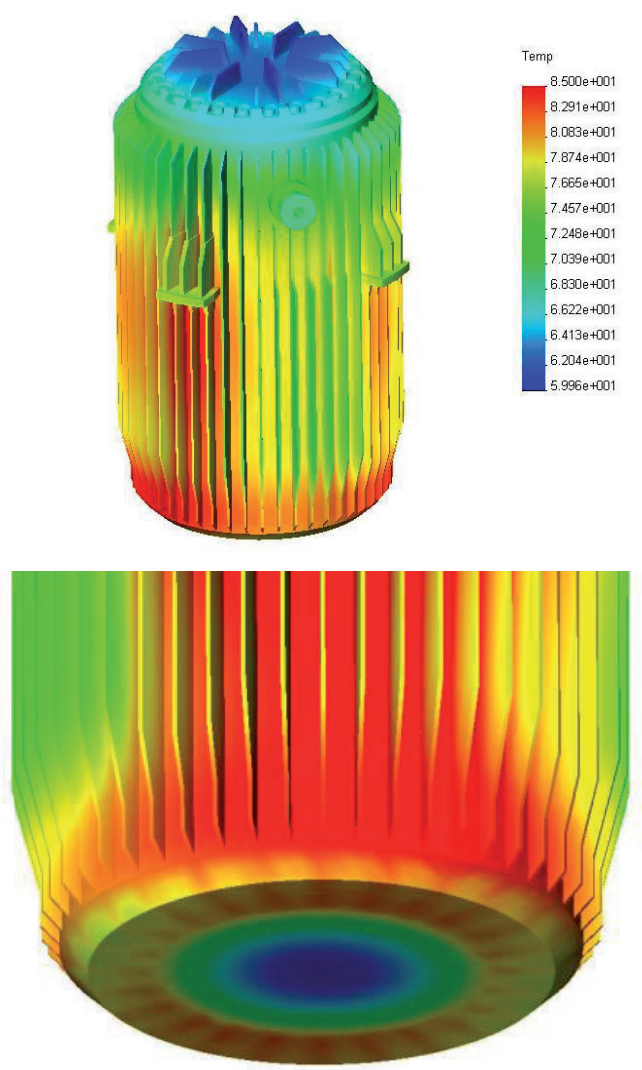

Fig. 10: Detail of temperature field on container surface.

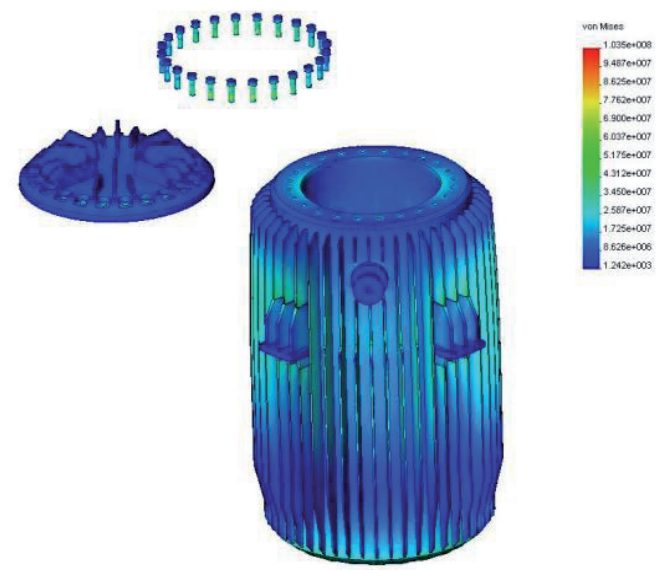

Fig. 11: Equivalent stresses in container.

tions 5 and 7 on the lid of container, were detected maximum stress levels $39 \mathrm{MPa}$ in ribs. The levels of principal normal stresses on the container lid did not exceed in their absolute values $5 \mathrm{MPa}$. The measured levels of stresses fully agree with results of computations for corresponding thermal field.
From the above-mentioned facts result that experiment is fully confirmed by the numerical calculations.

\section{Pressure Test of a Container Model}

Test by outer pressure allow verifying using model loading under operation conditions that are defined by Regulation No.57/2006 Z.z. of Nuclear regulatory authority of Slovak republic that gives details for transport conditions for nuclear materials.

After detailed analysis of results of computer verification of container and extensive consultations with operator, the decision was made that due to small stress levels and big stiffness of a lid and due to removing of coating color on the surface, that the strain-gage methods will be used for the measurement on the model of container.

The tests of model should confirm integrity of container as well as its internal volume under predefined operation and failure conditions. Application of strain-gages is seen from Fig. 12. The locations were chosen on the basis of computer verification of pressure test. a)

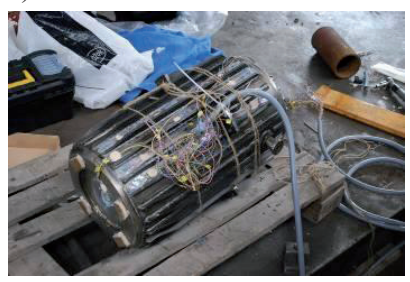

b)



c)

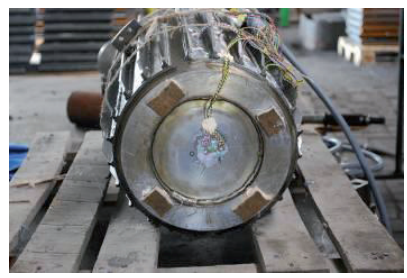


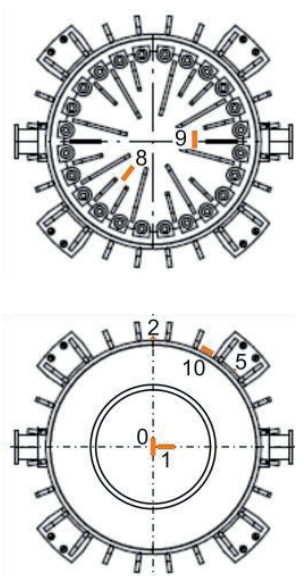

Fig. 12: Position of sensors for the tests by outside pressure. (a) on the body, (b) on the lid, (c) on the bottom part. 
During the pressure test the model was given into test tank filled by water (Fig. 13) and pressure to level of $300 \mathrm{kPa}$. During the measurement were measured strains in locations of strain-gages and also the tightness of the connection between lid and body was investigated.


Fig. 13: Positioning of model into test tank for providing external pressure tests.

Measurement on the model was realized in test tank by successive increasing external pressure from $50 \mathrm{kPa}$ to the pressure $300 \mathrm{kPa}$, with atmospheric pressure inside measured container. In Fig. 14 is shown dependency of radial $(r)$ and tangential (t) stresses on external pressure in selected locations of container model. The check of internal space after external pressure test confirmed that tightness between lid and the body of container was preserved.

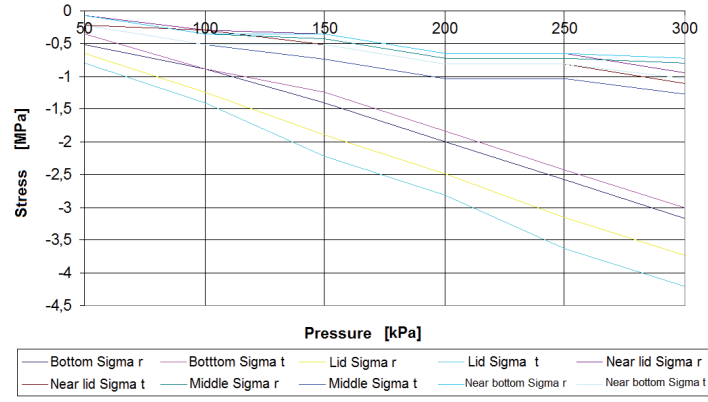

Fig. 14: Dependence of stresses in measured locations on external pressure.
The stresses in real container under external pressure $2 \mathrm{MPa}$ (according to regulations) were determined by numerical computation by the finite element method. In Fig. 15 are given fields of equivalent stresses according to von Mises theory. The principles of similarity theory using dimensionless Rayleigh method were applied during creation of model. Comparison of stresses gained by measurement on container with the stresses computed by the finite element method under external pressure leads to conclusion that ratio of corresponding principal normal stresses in lid of model and real container corresponds to ratio of external pressure. The same can be stated for the stresses on cylindrical surface of real container and container model. As the test by external pressure affords relevant data, it can be stated that results from experiments document tightness of real container.

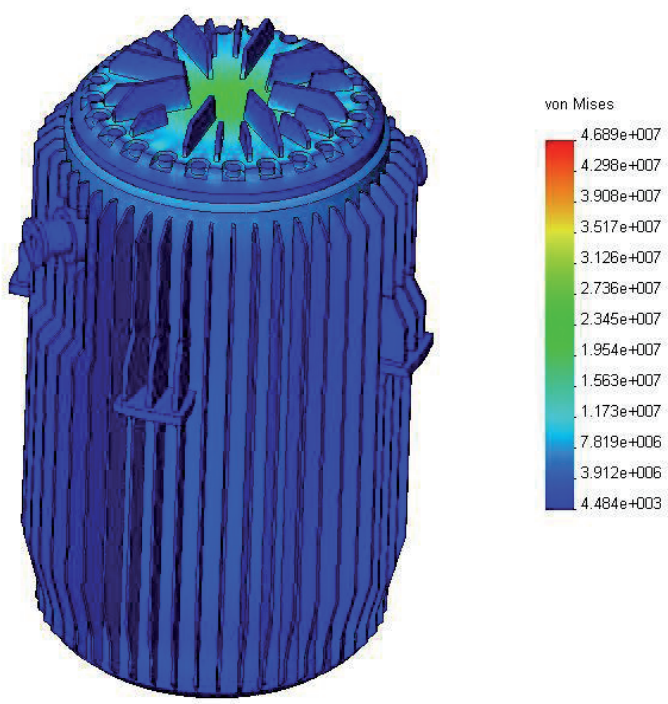

Fig. 15: Equivalent stresses on container under external pressure $2 \mathrm{MPa}$.

On the other side, external pressure $300 \mathrm{kPa}$ corresponds to hydrostatic pressure cca $30 \mathrm{~m}$. Immersing $200 \mathrm{~m}$ (with external pressure $2 \mathrm{MPa}$ according to Attachment No.4, Part IV, Section 19 [1]), corresponds according to similarity analysis to 6,6 multiple of pressure increasing. Because meridian and circumferential stresses as well as deformations are linear functions of loading, the biggest components of principal normal stresses in con- 
tainer model under pressure $2 \mathrm{MPa}$ do not exceed $25 \mathrm{MPa}$ and $28 \mathrm{MPa}$, respectively. Under atmospheric pressure inside container model, the equivalent von Mises stresses do not exceed value $27 \mathrm{MPa}$. The tightness of container increases with increasing immersion, on the basis of experiments can be concluded that container meets also this kind of conditions according to regulation No. 57/2006 Z.z. Accordingly, the experimental measurements on the model can be considered to be consistent with the results of computations by the finite element method on real container.

\section{Conclusion}

From the results of experimental and numerical analysis of thermal and stress states of transport container follows that these analyses give comparable results. Thermal fields created by system of electric heating coils inside of container corresponds to thermal and stress fields gained by numerical computation by the finite element method. It is obvious that important factor that influences precision of results is knowledge of physical constants inputting computation as well as precision of boundary conditions modeling of solved problem. The results of experiments and numerical computations are in substantial parameters the same.

As follows from results of pressure tests, maximal equivalent stress (in lid) of container model under external pressure $300 \mathrm{kPa}$ did not exceed $4 \mathrm{MPa}$. In the area of linear elasticity theory, under external pressure $2 \mathrm{MPa}$ (according to regulation) maximal equivalent stress in container model did not exceed $27 \mathrm{MPa}$, which is in accordance with results of numerical computations on real container. The results of tests confirmed after verification by numerical methods that suggested experimental procedures for verification of container safety are suitable for practical applications.

\section{Acknowledgments}

This article was created with support of grant projects VEGA 1/0937/12 Development of unconventional experimental methods for mechanic and mechatronic systems and VEGA 1/0393/14 Analysis of causes of mechanical systems failures by the quantification of strains and stress fields.

\section{References}

[1] Vyhláška č.57/2006, Z.z., UJD SR ktorou sa ustanovujú podrobnosti o požiadavkách pri preprave rádioaktívnych materiálov, zo dňa 12.1.2006.

[2] Trebuňa, F. et al. (2008). Metodika na vykonanie experimentálnych meraní a skúšok prepravného kontajnera na vyhoreté jadrové palivo C-30. Záverečná správa, SjF TU Košice, 2008.

[3] Trebuňa, F. et al. (2011). Typové merania a skúšky transportného kontajnera C30. SjF TU Košice, máj - september 2011.

[4] Trebuňa, F. et al. (2012). Dokumentácia na vydanie rozhodnutia o schválení transportného kontajnera C30 z hláadiska pevnostného posúdenia, termickej a tlakovej stability. SjF TU Košice, november 2012.

[5] Trebuňa, F. et al.(2012). Methodology for experimental verification of safety of packages for transport of spent nuclear fuel. In: Acta Mechanica Slovaca. Roč. 16, č. 3, s. 34-41. - ISSN 1335-2393.

[6] Wőlzke, H., Wolff, D., Qiao, L., Feutlinske, K., Zencker, J., Musolff, A. (2007). Topical BAM cask design evaluation using drop tests and numerical calculations: accidental cask drop without impact limiters onto a storage building foundation 15th Int. Symposium - PATRAM 2007, Miami, Florida, USA october 21-26, 2007

[7] Regulations for the Safe Transport of Radiactive Material IAEA Safety Standard Series No. TS-R-1, International Atomic Energy Agency, Vienna, 2005.

[8] Pástor M., Hagara, M. (2014). A comparison of modern and classical experimental methods of mechanics in strain investigation. In: Applied Mechanics and Materials. Vol. 611 (2014), p. 501-505. - ISSN 1660-9336.

[9] Trebuňa, F., Šimčák, F., Bocko, J., Trebuňa, P. (2010). Failure analysis of mechanical elements in steelworks equipment by methods of experimental mechanics. In: Engineering Failure Analysis. Vol. 17, no. 4 (2010), p. 787-801. - ISSN 13506307.

[10] Trebuňa, F., Šimčák, F., Bocko, J., Pástor, M. (2013). Analysis of causes of casting pedestal failures and the measures for increasing its residual lifetime. In: Engineering Failure Analysis. Vol. 29 (2013), p. 27-37. - ISSN 1350-6307

[11] Trebuňa, F., Šimčák, F. (2007). Príručka experimentálnej mechaniky. TypoPress, Košice, 2007. 